\title{
Extensive Listening and Its Relation Towards Vocabulary Knowledge
}

\author{
Nihta V.F. Liando* \\ English Education Department \\ Universitas Negeri Manado \\ Manado, Indonesia \\ *nihtaliando@unima.ac.id
}

\author{
Christine Pajow \\ Postgraduate English Education \\ Universitas Negeri Manado \\ Manado, Indonesia
}

\author{
Mister G. Maru \\ English Education Department \\ Universitas Negeri Manado \\ Manado, Indonesia
}

\begin{abstract}
Extensive Listening (EL), one of the approaches in language learning, is believed has a remarkable impact on the language proficiency of learners, particularly on the process of acquiring vocabularies. This study reports the systematic review of $E L$, and its relation towards vocabulary knowledge from the year 2016 onwards. Four studies are involved and reviewed in terms of: (i) participants (ii) national context, and (ii) main findings. The main findings represent both teachers and students' experiences on how EL affects learners' vocabulary acquisition. The results show that EL can be adopted to assist learners to absorb new vocabularies. Having such positive results, EL, therefore, is highly recommended for learners to enrich their lexicon. Several fundamental characteristics of EL and the essential recommendations are presented as it is helpful to gain a better comprehension for the acquisition process. Finally, the review provides some recommendations for the future EL study.
\end{abstract}

Keywords-extensive listening, vocabulary acquisition, listening and viewing, language learners

\section{INTRODUCTION}

From the beginning stage of learning language, vocabularies should be recognized as a central element in language instruction to develop learners' skills well [1]. Having adequate vocabularies is believed as one of the important factors that can facilitate comprehensible communication [2]. Vocabulary, therefore, is crucial, for it has a vital role to the language competence and literacy development [3]. The more vocabulary they have, the better understanding they may gain. Due to the importance of vocabulary, both language learners and language teachers seem to have one of the significant tasks to underpin the successfulness in learning a language [2].

Two common strategies of teaching and learning vocabularies that have been acknowledged by a number of researchers: intentional vocabulary learning and incidental vocabulary learning [2,4-7] have shown the evidences of enhancing learners' vocabularies knowledge. This happens through learners' exposure of language input, whether it is spoken or written input, gained by them. It is thus essential to engage language learners' with a large amount of listening and /or reading materials to provide various input, which further will affect their productive skills.

In the second language acquisition (SLA) field, a linguist namely Stephen Krashen has proposed the Input Hypothesis which claims that language learners need substantial comprehensible input [8], and similar to reading, listening extensively can provide abundant spoken input for acquiring new vocabulary [6]. Comprehensible input means the input received should be suitable to the listeners' level and intriguing to them [8].

\section{BACKGROUND}

In general, extensive listening (EL) has similar characteristics with extensive reading (ER). Both are known as the activity of listening or reading for pleasure. In doing ER or EL, learners commonly do not focus on the language content instead of immersing themselves to the materials which are being read or listened to obtain general information. Specifically, EL is defined as teaching and learning approach that allow learners to obtain a considerable amount of comprehensible and enjoyable listening input which will lead them to the meaningful listening practice [9].

Reference [10], cited in [9] examined two learners' main problems of listening laid on the 'speech rate' and 'distraction'. These two issues connect each other, where if the listeners listen to a very fast input, they naturally will get distracted and be unable to understand the coming information [9]. Given such issues, learners need to find the way to develop fast automatic processing of spoken input. Regarding this problem, 
$[9,11]$ believe that extensive listening may become one of the effective ways to develop automaticity in recognizing spoken language.

Extensive listening is considered has a remarkable impact, not only to increase listening comprehension but also to bring positive influences to the other domains of language teaching and learning. The study of [11] has reported six benefits of extensive listening and viewing: (1) increase students' motivation, (2) develop listening fluency and automaticity in recognizing spoken texts, (3) improve listening comprehension, (4) provide learning flexibility, (5) increase independence learning, and (6) underpin the use of L2 in the real life setting.

Moreover, the primacy of EL can also be reassuring as it may facilitate incidental vocabulary learning or what so-called vocabulary acquisition, which will promote retention if learners receive an input in a meaningful way [2], yet it can be a timeconsuming process [6]. It is because "vocabulary learning is not an all-or-nothing piece of learning", but it is a gradual process that relates at every meeting, whether to add a new vocabulary or to strengthen the existing vocabulary from previous meeting [12].

EL is not solely an activity to listen to the aural input. It is distinguished into five types. First, listening only, which is a listening activity that can be done together with another activity, such as jog, cook, or drive. However, this activity may be tough for learners at the beginner or pre-intermediate level. Thus, to conduct this activity, it is essential to pick up listening materials which suitable to students' level. Second, active listening (shadowing/overlapping while listening). Overlapping refers to reading aloud the script while listening [11] while shadowing means learners imitate the pronunciation and intonation without looking at the script [13]. This activity provides an occasion for learners to improve their pronunciation or spoken language [14]

Furthermore, when the scripts or texts are downloadable, learners can simultaneously reading and listening to the texts. This activity is known as reading while listening, as the third activity of EL. In conducting reading while listening, which is more comprehensible and enjoyable, learners are likely to develop their vocabulary and recognize the pronunciation of each vocabulary that have been known by them earlier. This approach is also considered efficient for English as foreign language (EFL) learners, in particular for young learners, because it can develop both quantity and quality of second or foreign language input [15].

Moreover, the fourth activity is listening and viewing. In recent years, a lot of videos or movies are easier to be downloaded. Although they are not created for pedagogy purposes, they can be beneficial resources for language learners. Employing graded reader audiobooks or authentic television programs seems to be well-suited sources of aural input [16] as it promotes students' learning autonomy and speaking fluency [11]. The fifth activity is combined listening, viewing, and reading, which is usually conducted via movies with the subtitles of the target language. By infusing audiovisual materials in language classes, learners gained more comprehension and vocabulary improvement [2], which also contribute to the incidental vocabulary learning [17]. Thus, this activity is considered helpful for learners due to the availability of the movies' caption.

Looking back to a study who has investigated the potential of vocabulary acquisition through ER [6], hence by having similar purposes with a different way only, a study on EL has attracted several scholars' attention. It is thought can embody language learners' proficiency, such as pronunciation awareness, vocabulary acquisition [18], intonation or accent familiarity [14], and so forth. Nevertheless, in the very beginning experience of conducting EL, it is most likely to be challenging for learners, especially for the beginner. They assume that listen to the native or fluent speaker of English is challenging as well as perplexing, occurred not because the content is tough, but because the speakers spoke too fast [19]. As a result, it is difficult for learners to process the incoming data.

On the other hand, language learners need to listen to the native speaker speaking to them, so that they may have familiarity to the real characteristics of the spoken language. Furthermore, in the language classroom context, listening comprehension is crucial, because learners cannot clearly understand the materials delivered without being able to listen to their teacher. Thus, EL is highly recommended to be incorporated in the language classroom to stimulate learners to practice listening, and further they can actualize it outside the classroom. Given such issues, the writer considered, it is pivotal to conduct review about how EL experience by learners and practitioners, its usefulness and potential to enrich learners' vocabulary knowledge.

This review was carried out to examine both EFL teachers and students' strategy in implementing EL in the last 5 years, and answered the following research questions:

- Where were the studies conducted?

- Who were the main participants of the study?

- What were the main findings?

\section{METHODS}

A systematic review is a research method itself through a rigorous examination of relevant study according to explicit criteria to answer specific questions [20]. However, in the education field, this term tend to be used loosely [21]. Different versions of the systematic review has guided this review, and the design has been constructed loosely around the method outline by Petticrew [22]. This systematic literature review encompasses eight steps as follows:

- Defining the parameters, questions, and choosing keywords, inclusion and exclusion criteria and databases.

- Carrying out the literature search. 
- Screening the references.

- Assessing the remaining studies against inclusion and exclusion criteria.

- Assessing quality.

- Extracting the data into a summary table of information

- Synthesizing the studies to answer the research question

- Writing up the report.

In finding the articles, researcher used key search terms, which are "extensive listening", or "vocabulary acquisition", or "incidental vocabulary", or "listening and vocabulary". The data were gathered from electronic journal database namely Google Scholar. Four studies from twelve were included in this review after following the inclusion and exclusion criteria.

\section{A. Inclusion Criteria}

To determine the inclusion criteria, researcher identified by reading the full paper of reviewed study. The chosen study should follow the following criteria:

- The research that focused on extensive listening.

- The research carried out in English as a foreign language (EFL) context.

- The research that only focused on non-native speaker.

- The research reported in English peer-reviewed academic journal whose full text can be accessed online.

- Academic publication from 2016 - 2020.

\section{B. Exclusion Criteria}

The studies were excluded if they were:

- $\quad$ The studies before 2016 .

- The studies that not focused on extensive listening.

- The study that not discussed vocabulary acquisition.

The researcher were identified 14 research articles that related to the topic. The number was noticeably reduced after applying the inclusion and exclusion criteria to 4 articles. The information of those reports was extracted into a summary table with the following headings: (1) Participants, (2) Main findings. In depth review, the collected information were synthesized to answer the research questions.

\section{FINDINGS}

Figure 1 represents the national contexts and amount of participants of the reviewed study. Three countries are included in the reviewed study: (1) Indonesia, (2) Taiwan, and (3) Colombia. The participants are from students $(n=56)$ and teachers $(n=27)$. It is worth mentioning that the participated teachers derive from several countries including Indonesia, Japan, Thailand, Vietnam, Mongolia, and Mexico. Based on the total of participants, it can be drawn that students are the major participant followed by the teachers. The role of the teachers participating in the study is to demonstrate their experience in implementing EL in the language classroom. Additionally, students are the subject to practice EL, which are dominated by EFL undergraduate students.

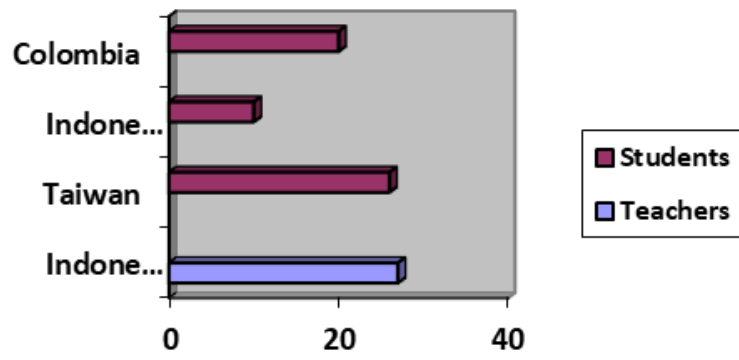

Fig. 1. Total of Participants and National Context.

Four reviewed articles involving both teacher and students as participants admit that EL is worthwhile undertaking. Although there are a lot of material preferences for EL, learners should be more selective to pick one of them due to the varieties of level difficulty, which can affect learners' interest and understanding. After following the training, students perceive EL is beneficial, because it provides them much of input from the spoken language. However, there are critical factors that sustain students' motivation in practicing EL. The other aspect which is also crucial, is the result of EL cannot be seen in a short time, instead it requires a long time period to be implemented. The following table presents them more clearly.

TABLE I. MAIN FINDINGS

\begin{tabular}{|c|c|c|c|}
\hline Themes & $\begin{array}{c}\text { Material } \\
\text { Preference }\end{array}$ & Remarkable Outcomes & $\begin{array}{l}\text { Critical } \\
\text { Factors }\end{array}$ \\
\hline $\begin{array}{l}\text { EFL } \\
\text { Teachers' } \\
\text { Experience } \\
\text { in EL [23]. }\end{array}$ & $\begin{array}{l}\text { Discovery } \\
\text { Channel } \\
\text { National } \\
\text { Geographic } \\
\text { Channel } \\
\text { Animal } \\
\text { World } \\
\text { Disney } \\
\text { Cartoons } \\
\text { News } \\
\text { Podcast }\end{array}$ & $\begin{array}{l}\text { The longest time the } \\
\text { teachers spent in doing } \\
\text { EL was } 10 \text { years and } \\
\text { the least was less than } 1 \\
\text { year. Two teachers } \\
\text { which have been } \\
\text { interviewed have been } \\
\text { practiced EL routinely } \\
\text { even one teacher do not } \\
\text { let his time pass } \\
\text { without doing EL. As a } \\
\text { result, they } \\
\text { acknowledged they } \\
\text { gained vocabulary } \\
\text { enrichment as well as } \\
\text { sharpen their listening } \\
\text { skill. }\end{array}$ & $\begin{array}{l}\text { Having } \\
\text { pleasure and } \\
\text { entertainment } \\
\text { \& being } \\
\text { motivated to } \\
\text { enhance } \\
\text { listening } \\
\text { proficiency, } \\
\text { including } \\
\text { vocabulary } \\
\text { enrichment. }\end{array}$ \\
\hline
\end{tabular}


Table 1. Cont.

\begin{tabular}{|c|c|c|c|}
\hline $\begin{array}{l}\text { Comparing } \\
\text { Students' } \\
\text { Own Efforts } \\
\text { and } \\
\text { Teachers' } \\
\text { Guidance in } \\
\text { Listening } \\
\text { Class [24]. }\end{array}$ & CNN News & $\begin{array}{l}\text { The result of both } \\
\text { groups showed } \\
\text { significant vocabulary } \\
\text { gained from pretest to } \\
\text { delayed posttest. In EL } \\
\text { group, particularly, the } \\
\text { participants } \\
\text { highlighted, learning by } \\
\text { themselves can develop } \\
\text { their own } \\
\text { learning/practice style. } \\
\text { Two participants } \\
\text { applied } 3 \text { steps: First, } \\
\text { listening only (to } \\
\text { evaluate their } \\
\text { understanding of the } \\
\text { news). Second, } \\
\text { listening while reading } \\
\text { the script (to look up } \\
\text { the unknown } \\
\text { vocabularies), and third } \\
\text { listening only as the } \\
\text { first step to have more } \\
\text { comprehension of the } \\
\text { news. }\end{array}$ & $\begin{array}{l}\text { Interesting } \\
\text { materials with } \\
\text { visual effect \& } \\
\text { learning } \\
\text { environment. }\end{array}$ \\
\hline $\begin{array}{l}\text { Exploring } \\
\text { posibilities } \\
\text { of } \\
\text { autonomous } \\
\text { learning } \\
\text { through EL } \\
\text { course [25]. }\end{array}$ & $\begin{array}{l}\text { YouTube } \\
\text { TED.Ed }\end{array}$ & $\begin{array}{l}\text { Most of the students are } \\
\text { mostly benefitted } \\
\text { vocabulary learning and } \\
\text { the variety of English. }\end{array}$ & $\begin{array}{l}\text { Self-selection } \\
\text { materials. }\end{array}$ \\
\hline $\begin{array}{l}\text { Process, } \\
\text { Product, } \\
\text { Perceptions } \\
\text { of EL in } \\
\text { Colombian } \\
\text { University } \\
\text { [26]. }\end{array}$ & News & $\begin{array}{l}\text { After having } \\
\text { approximately } 96 \\
\text { minutes and } 42 \text { seconds } \\
\text { for each students, and } \\
\text { writing down their own } \\
\text { audio journal, students } \\
\text { found that EL was } \\
\text { obviously a productive } \\
\text { activity, which have } \\
\text { helped them in } \\
\text { absorbing new } \\
\text { vocabularies. }\end{array}$ & $\begin{array}{l}\text { Sense of } \\
\text { independence } \\
\text { activity \& the } \\
\text { authenticity of } \\
\text { the materials. }\end{array}$ \\
\hline
\end{tabular}

Good teachers are those who teach what they have been done earlier, so that they can be a role model for their students. It can be seen in Table 1 showing several EFL teachers have been employing EL in their daily basis. Surprisingly, the length time spending by some teachers is about $6-10$ years. The least time is only less than one year. Uniquely, one of the teachers really make use of EL by spending his spare time to listening extensively. In conducting EL, the teachers acknowledge that EL remarkably contributes to the improvement of their language proficiency. One teacher points out that he acquires new vocabularies the most compared with the other merits he may gain [23]. From the result, it can be drawn that the more practice they make, the more benefit they may absorb.

Furthermore, in the students' context, particularly university students, the results shows that EL promotes autonomous learning. The comparison between students' effort and teacher-guided instruction in EL resulted a significant improvement for students' vocabulary knowledge, which means both methods are useful [24]. However, in the language classroom, students appear to carry out EL by themselves, because each of them has their own learning style. Some students tend to practice without teacher-guided instruction, because they prefer to discuss with their peers if they find any difficulties, which can also create a meaningful process of learning. This does not mean the teachers' guidance is unnecessary, instead collaborative learning also play an important role. The study concludes that both methods are helpful for vocabulary learning as well as retention.

The dominant approach conducted by students in EL is listening and viewing. This approach seems to be the most suitable strategy for students. The critical factors that sustain students' motivation are the audiovisual and self-selection materials, and the learning environment. These three aspects will make EL even more intriguing, lead to the independency to choose the materials based on students' own pace, and make students be more focused. These factors are crucial because the different ability of students in understanding the aural input. Finally, the students acknowledge that EL fosters their productivity, and aids them to be acquainted with the various English accents [26].

Turning to the time needed to conduct EL, a substantial period amount of time are required. The classroom practices serve to encourage students to have another exposure outside the classroom. Henceforth, they are expected to spend more time beyond their time of studying language in the classroom [23].

\section{DISCUSSION}

This systematic review has provided a descriptive picture concerning the contribution of EL towards learners' vocabulary knowledge. The results of the review will be discussed below.

Most of EL practices take place in Asia region. One study involves some teachers from different countries in Asia. Interestingly, EFL students in Colombian university whose first language is Spanish, also employ EL as the approach to increase their skills. While EL is likely has been broadly known by the Asian language teachers, it seems that many Indonesian' teachers have realized the advantages of EL, so they may regularly incorporate it in the language classroom. This is supported by several studies regarding EL in Indonesia, and a teacher who has been implementing EL for about 10 years as described in Table 1 [11,23]. Since the students may have limited exposure when studying inside the classroom, this report may trigger other Indonesian learners and teachers to have more time to elevate their skills outside the classroom through EL.

For participants, students at the tertiary level are the majority participants of this reviewed studies. Students' level are intermediate or at the B2 level according to CEFR. This means that listening extensively is less likely to be conducted for the school students or students at the beginner level. However, due to the flexibility of EL, all learners should be 
able to actualize EL regardless their level. Prior study [11] that has mentioned an ease of learner to choose the materials which fit to their level should be maintained. This makes EL is motivating, as a result the purpose of learning new vocabulary can be achieved easily.

The main findings cover the way of how students and teachers gain the benefit of EL towards their vocabulary knowledge, time they need, and the accessible materials. Among the multimodal of EL, the participants of the reviewed studies utilize various types. Listening and viewing is the most used, followed by listening only. As the majority of the participants are intermediate one, they normally have a better understanding towards the listening input. Listening and viewing aids learners to be better understand the input due to the audiovisual presented. Although there is no subtitle provided, learners may absorb the vocabularies through the video played. Listening only and reading while listening, which are also chosen by one of authors in reviewed study, yields vocabulary learning [24]. It seems that the types of EL are chosen should fit to learners' level. Listening and viewing or listening only is best suited to the B2 level [23,24,26], while reading while listening is applied to $\mathrm{B} 1$ or lower as it is applied by Saputra [25] to the freshman.

This may teach both learners and teachers that the comprehending process occurs gradually depending on the learners' level when they begin EL. Beginner learners are encourage to focus on the easier or slower speech rate, or can apply listening while reading or combined listening, viewing, and reading type, until they generate a progress to the subsequent level [11]. The process of selecting materials is crucial to underpin comprehensible input. This, therefore, accords with Krashen [8], who mentioned that comprehensible input means when the acquirers have prior knowledge from the input outside the classroom, and when they proficient enough to understand at least some of the spoken language.

In this case, particularly, the materials selection is done by the teachers, in which the news report is the most preferred one. It can be assumed that the teachers seek for the appropriate materials which can be comprehended by the students. Further, the materials can be access easily as has been presented in the Table 1. Even though news report video, YouTube, TED, and/or Podcast are chosen in the reviewed studies, there is also another great source which has not been utilized, such as ELLO (English Listening Lesson Library Online). ELLO's website (ello.org) provides monologue, conversational, and graded materials which is available online and worth visiting.

It is clear that the chosen materials have strong relation with the speech rate. An effortless material is indicated by a slower speech rate. Since half of the material is a news report, the speech rate, however, would not be slow. Therefore, the listeners are those who are at the upper intermediate level. It is also similar to the teachers in the reviewed study, who conducted EL by listening to more authentic materials, such as movies and other authentic materials from YouTube [23]. Both teachers and high proficiency students may gain new vocabulary incidentally through the aforementioned materials Nevertheless, Renandya [9] have highlighted that lower proficiency students can also adopt EL to assist vocabulary acquisition by listening to the graded materials as suggested above. In addition, video from YouTube can also be used for lower proficiency students, yet the materials should be more straightforward.

Regarding time, EL need to be undertaken over the extended period of time. Commonly, the review studies are conducted in three months to obtain the result. The suggestions of the evidences point out that EL should be applied in approximately 6 months [19], while in ER context, the effect will be stronger and durable when students spend an entire year regularly [27]. Thus, to be able to acquire vocabulary, three months seems to be a minimum time in conducting EL. It is also worth mentioning that the most useful is when students employ EL as a lifelong learning process.

After passing the time needed, the listeners finally can grasp new vocabularies as in the reviewed studies confirm so. However, EL can be effectively practiced when learners consider to practice it pleasurably, not as a burden, by choosing enjoyable topics and speech rate that fits to their level. Furthermore, EL requires learners' consistency and commitment to devote abundant time as well as dive in a wide range of materials of the target language.

\section{CONCLUSION}

In conclusion, this systematic review has provided the contribution on language teaching field regarding EL which is believed can increase learners' vocabulary knowledge as long as it is appropriately implemented. Selecting an appealing and convenient material, and conducting ample practice of EL will become the key. The more they listen, the more extended their vocabulary.

Finally, the present review study is expected to raise the language teachers and students' awareness of EL which could bring a positive impact towards their vocabulary knowledge. Future review study on this current topic, where the investigation of the effect of EL on learners' speaking and pronunciation, is recommended. In addition, a study to find out the effect of EL towards the lower proficiency students' vocabulary is worth investigating.

\section{REFERENCES}

[1] N.V.F. Liando, J.D. Adam, and T.K. Londa, "Efforts and difficulties in teaching vocabulary $3^{\text {rd }}$ AES2019 Proceedings," pp. 572-576, 2018.

[2] A. Karami, F.A. Bowles, "Which strategy promotes retention? Intentional vocabulary learning, incidental vocabulary learning, or a mixture of both?," Australian Journal of Teacher Education, vol. 44, no. 9, pp. 24-43, 2019.

[3] D.T.A. Lin, A. Pandian, P. Jaganatha, "READ+ vs. READ: Investigating extensive reading and vocabulary knowledge development among Malaysian remedial ESL learners," The Journal of Asia TEFL, vol. 15, no. 2, pp. 349-364, 2018. 
[4] 4. A. Cervatiuc, "Incidental learning of vocabulary," TESOL Encyclopedia of English Language Teaching, 2018.

[5] 5. Z. Jin, S. Webb, "Incidental Vocabulary Learning through Listening to Teacher Talk," The Modern Language Journal, pp. 550-566, 2020.

[6] YH. Wang, "Incidental Vocabulary Learning through extensive reading: a case of lower level EFL Taiwanese learners," The Journal of Asia TEFL, vol. 10, no. 3, pp. 59-80.

[7] H. van Zeeland, "Vocabulary in listening," TESOL Encylopedia of English Language Teaching, 2018.

[8] S.D. Krashen, Principle and Practice in Second Language Acquisition. Pergamon Press Inc, 1982

[9] W.A. Renandya, T.S.C. Farell, "Teacher, the tape is too fast! Extensive listening in ELT," ELT Journal, vol. 65, pp. 52-59, 2011.

[10] Y. Zeng, "Metacognitif instruction in listening: a study of Chinese nonEnglish major undergraduates," Unpublished MA Dissertation, National Institute of Education, Nanyang Technological University, Singapore.

[11] F.M. Ivone, W.A. Renandya, "Extensive Listening and Viewing in ELT," TEFLIN Journal, vol. 30, no. 2, pp. 237-256, 2019.

[12] P. Nation, "Learning Vocabulary in Another Langugae," Cambridge: Cambridge University Press.

[13] T.M. Agustinus, N, Rini, and M. Clark, "A Study on English Listening Activity of "Shadowing" in Indonesian Students," Journal of Social Sciences and Humanities, vol. 9, no. 1, pp. 88-99, 2019.

[14] Y. Hamada, "Shadowing: For better understanding accented englishes," The Journal of ASIA TEFL, vol. 16, no. 3, pp. 894-905, 2019.

[15] E. Tragant, A. Vallbona, "Reading while Listening to Learn: Young EFL Learners' Perception,” ELT Journal, vol. 72, no. 4, pp. 395-404, 2018.

[16] M.P.H. Rodgers, "Extensive Listening and Viewing: The Benefits of Audiobooks and Television," The European Journal of Applied Linguistics and TEFL, vol.5, no. 2, pp. 43-57, 2016.
[17] Y. Feng, S. Webb, "Learning Vocabulary through Reading, Listening, and Viewing: Which Mode of Input Is Most Effective? Studies in Second Language Acquisition," Cambridge University Press, pp. 1-25, 2019.

[18] S.D. Krashen, “The Case for Narrow Listening," System, vol.24, no.1, pp. $97-100,1996$

[19] W.A. Renandya, G.M. Jacobs, "Extensive Reading and Listening in the L2 classroom. In W. A. Renandya, \& Handoyo, (P). (Eds.)," English Language Teaching Today, New York, NY: Routledge, pp. 97-110., 2016

[20] C. Torgerson, Systematic reviews. London, UK: Bloomsbury Publishing, 2003

[21] M. Bearman, C.D. Smith, A. Carbone, S. Slade, C. Baik, M. HughesWarrington, and D.L, Systematic review methodology in higher education. Higher Education Research \&, 2012.

[22] M. Petticrew, H. Robert, Systematic reviews in the social sciences: A practical guide. Malden, MA: Blackwell Pub, 2006.

[23] K.D. Pramuji, R. Waring, and E. Kurniawan, "EFL Teachers' Experiences in Developing L2 Proficiency through Extensive Listening", TEFLIN Journal, vol. 30, no. 2, pp. 257-273, 2019.

[24] FY. Yang, C. Hung, "Is Listening All about One's Own Effort? A Comparison Study," The CATESOL Journal, vol. 30, no. 2, pp. 43-63, 2018.

[25] Y. Saputra, A.S. Fatimah, "The use of TED and YOUTUBE in Extensive Listening Course: Exploring possibilities of autonomy learning," Indonesian Journal of Language Teaching, vol. 13, no. 1, pp. 73-84, 2018.

[26] C.A. Mayora, "Extensive Listening in a Colombian University: Process, Product, and Perceptions", HOW, vol. 24, no. 1, pp. 101-116, 2016.

[27] S.D. Krashen, The Power of Reading ( $2^{\text {nd }}$ ed.), Porstmouth, NH: Heineman,

2004. 